\title{
Human protein-protein interaction prediction
}

\author{
Mark D McDowall, Michelle S Scott, Geoffrey J Barton \\ From Sixth International Society for Computational Biology (ISCB) Student Council Symposium \\ Boston, MA, USA. 9 July 2010
}

\section{Background}

In the scientific literature and large public databases there are currently only $\sim 39000$ human protein-protein interactions that have been experimentally confirmed out of a potential 330,000,000 (assuming 1 protein per gene). To bridge the gap, computational methods are required to guide further experimental endeavours.

\section{Results}

The PIPs framework [1] uses a naïve Bayesian method that combines the predictive capabilities of numerous features to calculate the likelihood of interaction between two proteins. Features considered by the predictor include co-expression, orthology, domain co-occurrence, post translational modification and a new feature analysing semantic similarity of Gene Ontology terms. The predictor now includes two modules that make predictions based on the topology of the predicted protein-protein interaction network. We predict 318800 interaction predictions of which 310732 (96.3\%) are not present within other publically available databases. Several of the predictions have been experimentally validated by external groups.

The PIPs website (http://www.compbio.dundee.ac.uk/ pips) [2] is an easy to use system to explore the predictions that have been made. Searches can be initiated by querying with a protein identifier (IPI, RefSeq or UniProt) or via a keyword search. All predicted protein-protein interactions are returned ranked by their likelihood of interaction. The website allows the user to analyse the evidence used to calculate the likelihood of interaction and provides links through to external databases and publications to retrieve the source data.

\section{Conclusions}

The set of predictions that have been made in this work increase the coverage of the human interactome and help guide future research.

\section{Acknowledgements}

We would like to thank Dr. T Walsh for computational issues and all members of the Barton Group for helpful discussions. This work was supported by a BBSRC studentship to MDM and a CIHR Fellowship to MSS.

Published: 7 December 2010

\section{References}

1. Scott MS, Barton GJ: Probabilistic prediction and ranking of human protein-protein interactions. BMC Bioinformatics 2007, 8:239.

2. McDowall MD, Scott MS, Barton GJ: PIPs: Human Protein-Protein Interactions Prediction Database. NAR 2009, 37:D651-D656.

doi:10.1186/1471-2105-11-S10-P1

Cite this article as: McDowall et al:: Human protein-protein interaction prediction. BMC Bioinformatics 2010 11(Suppl 10):P1.

Submit your next manuscript to BioMed Central and take full advantage of:

- Convenient online submission

- Thorough peer review

- No space constraints or color figure charges

- Immediate publication on acceptance

- Inclusion in PubMed, CAS, Scopus and Google Scholar

- Research which is freely available for redistribution

Submit your manuscript at www.biomedcentral.com/submit
() Biomed Central 